\title{
The Novelty Of Developing Authentic Assessment On Scoring Rubric For The English Teachers To Run The National Curriculum In South Sumatera, Indonesia
}

\author{
Elsina Sihombing \\ \{elsina.sihombing@yahoo.co.id\} \\ Institut Agama Kristen Negeri Tarutung
}

\begin{abstract}
Absract. In Indonesia curriculu has been revised frequently and the last result named K'13, which is derived from 2013 curriculum launching. The curriculum having one main point that makes it differs from the former curriculums, namely its elements, especially learning measurement standard using authentic assessment. Authentic assessment recommends Contextual Teaching and Learning (CTL) combined with scientific learning methods, as the methods of learning at schools. Contextual learning is a concept of learning in which the teacher help the students to parallelize the content of learning to the real context around the society and togetherly tailoring the knowledge to the students so that they can actualize it in daily life, whereas scientific learning, the teachers help the learners to explore the content of learning empirically, see (Depdiknas, 2013). This research belongs to $\mathrm{R} \& \mathrm{D}$ research using concurrent sequential mixed research. The data was reduced by displaying, analyzing, and reducing the raw data of qualitative and quantitative, as well. At the end of the study, the product of this research was a model of authentic assessment of scoring rubric for English teachers, entitled "English Scoring Rubric of Authentic Assessment", a guide book for the teachers. The result of the study found that, t-obt.: 4.6 is much exceeds t-tab with degrees of freedom (df) $22-2=20$ in two-tail test at significant level of either $\alpha 5 \%(1.721)$ or $\alpha 1 \%(2.518)$ it was simply symbolized numerically with $; 1.725<4.6>2$. 528. It indicated that quantitatively, alternative hypothesis (Ha) is accepted and automatically null hypothesis ( $\mathrm{H} 0)$ is rejected, because t-obtained is more than t-tab with degrees of freedom (df) 20 (22-2) with two tailed test. It means that the designed model of scoring rubric was practical and effective to use by the English teachers in Lubuklinggau South Sumatera, Indonesia.
\end{abstract}

Keywords : Scoring rubric, Authentic Assessment, National curriculum ( K-`13 )

\section{Introduction}

Different curriculum period needs different goals or objectives, and of course different content, see zais ( 1996 ). This condition can influence the teacher steadiness to run the changing goals, from K-'13 to KTSP and back to K-'13 (revision) each in a short period. It made all the teachers being confused and did not know what to do to fulfill what the last curriculum (K-'13 revision) claims to, especially dealing with assessment and evaluation. They have known that K-' 13 is empowered with its specific assessment system, but they did not know what the elements of authentic assessment were, to be done. In this study, there were seven segments as the content of the model developed throughout the authentic assessment of scoring rubric, they were : Behavior assessment, Product assessment, self- assessment, and 
peer- assessment, portfolio, project, and written test as reliable and valid instrument of evaluation, particularly suitable for assessing the real achievement based on the real life. This reflective model encourages students to become involved in their learning, and promote positive attitude change in the fostering of life-long learning skills and further become responsible citizens.

\section{Discussion}

\subsection{The Concept of Authentic Assessment}

Assessments should be authentic and include alternative and integrated performancebased assessments (performance assessment is also called authentic assessment, alternative assessment, and performance testing). Performance-based assessment is characterized by diagnostic measurement, which identifies the learners' strengths and weaknesses, (see Joyce, at al, 2003. The purpose of this authenticity is to make the students to master bold understandings. It is also generalized by Stufflebeam that a process of assessment is an ongoing examination on a plan implementation and documentation of the process, that aims to remains feed back and improvement, see Stufflebeam $(2007 ; 341 . \quad$ K-'13 curriculum recommends the use of an approach, it is Contextual Teaching and Learning (CTL), for public schools in Indonesia.

\subsection{The Concept of Scoring Rubric}

In $\mathrm{K}$-'13 curriculum, it is defined that authentic assessment is the process of gathering and analyzing information about the students for the purpose of measuring learners achievement during the process of learning in continuum, see (Permendikbud no. 23, 2016). In these rules, the Government in the minister of education has written decision briefly stated that type of assessment for primary, secondary, and Senior High schools is authentic assessment by implementing scoring rubric. Scoring rubric involving both numeric and description to measure the 3 domains; affective, cognitive, and Psychomotor. Scoring the learners achievement should be in criterion-based which is termed as KKM (Kriteria Ketuntasan Minimal) or MMC (Minimal Mastery Criterion). In this study, there are seven segments as the content of the model that will be developed throughout the authentic assessment of scoring rubric, they are : Behavior assessment, Product assessment, self- assessment, and peerassessment, portfolio, project, and written test.

\section{Method Of Development}

This research belongs to Mixed Research focusing on Concurrent sequential technique. In conducting such a type, the starting point was by carrying out both the methods together namely qualitative and quantitative due to the research problems and the objectives of the research methods. The model of development is adapted and developed from R2D2-model (by Willis 2000). At the first time, R2D2 model ( Recursive, Reflective, Design, and Development) is initiated to develop Instructional Design in teaching qualitative research subject by Willis in 1995, (see Willis, 2000). But in this study, the researcher developed a 
model of scoring rubric of authentic assessment, which is valuable and helpful for the teachers especially English teachers.

The product of the research is named English Scoring Rubric of Authentic Assessment The cyclus of model development is as the following :

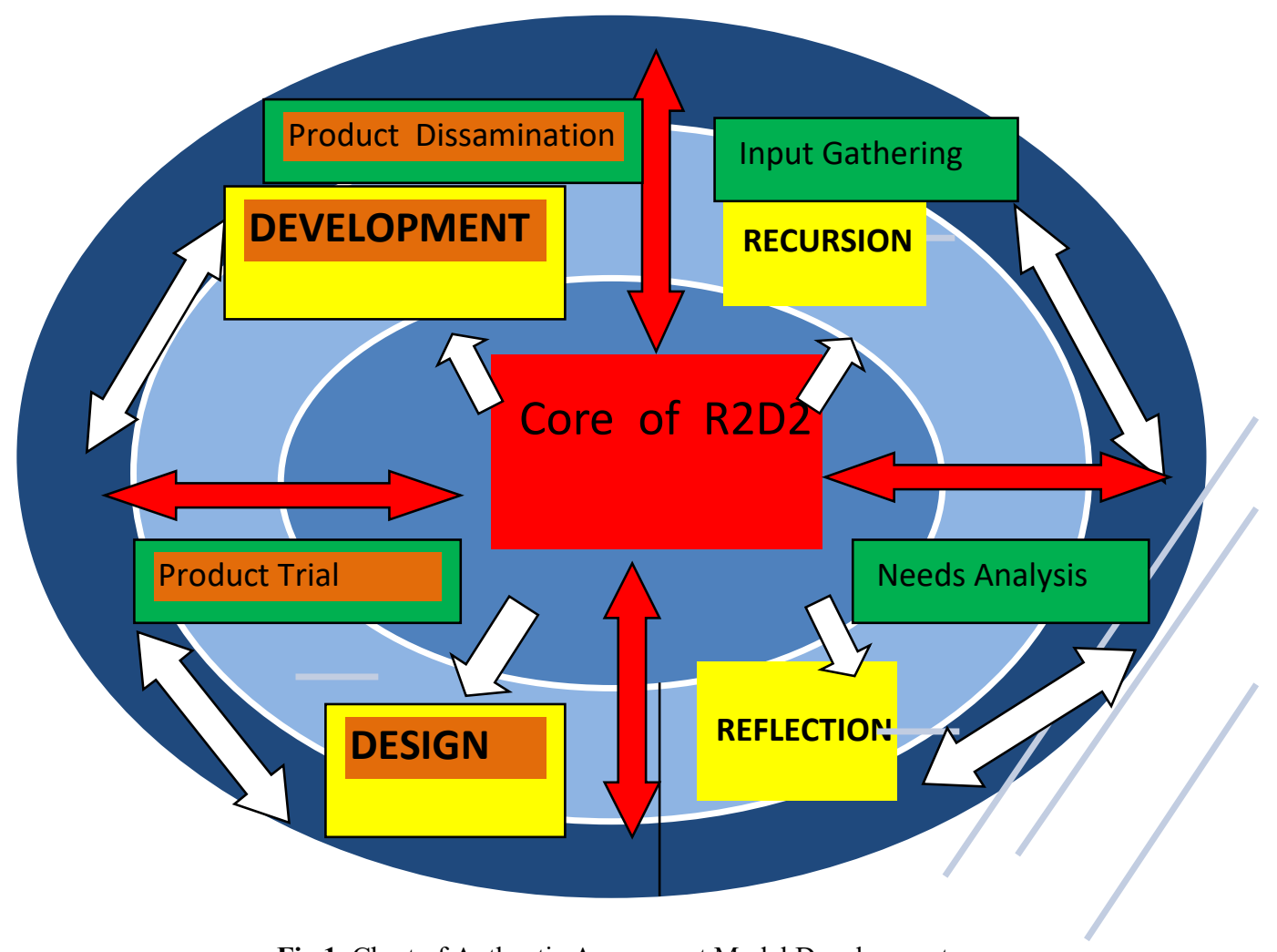

Fig.1. Chart of Authentic Assessment Model Development

The product of this study is a guide book of English Authentic Assessment Model that covers (a) assessment planning, (b) assessment specification, (c) assessment rubrics, (d) evaluation standard, and (e) final score.

\section{Conclusion}

The novelty of the research that was found that authentic assessment using scoring rubric was fundamentally help the English teachers to measure the students achievement of learning reasonably, which means that no score was subjectively given for the learners that based on the teachers' feeling but should be based on the standard of rubric, instead. The Development of the scoring rubric model was based on the assumption that the context of use was critically 
important. In this step, the designed model was developed throughout some procedures in which it needed participatory team that guided the process. This team typically includes instructional designers (in this case the researcher), forum group discussion ( validators ), subject matter experts ( teachers ), and students. The members of the team were often referred to stakeholders.

\section{Guiding Syntax}

a. doing a preliminary study dealing with the research problem

b. treasuring the preliminary data to find needs of the stakeholders in the schools

c. designing the frame of work, what to do during research conduction, structuring a group discussion forum (GDF) as the validation team..

d. running-down the design of works and controlling the way of what and how to do.

\section{Reference}

[1] Ansyar, Mohammad. 2014. Kurikulum ( Hakikat, Fondasi, disain \& Pengembangan). Jakarta. Penerbit Kencana Prenada media Group.

[2] Bloxham \& Boyd. 2007. Developing Effective Assessment in Higher Education. New York. Open Univ. Press.

[3] Boundless. Maslow's Theory in Boundless Psychology. https://www.boundless.com/psychology/textbooks/boundless-psychology. retrieved by June 18 th, 2016.

[4] Burns, Robert. 1995. Research Method. Australia. Longman Australia Ptd, Ltd.

[5] Field, Andi. 2005. Discovering Statistics Using SPSS. London. Sage Publication.

[6] Frankle \& Wallen. 1993. How To Design and Evaluate Research. New York. McGraw-Hill Inc.

[7] Gay, L.R. 1980. Educational Evaluation \& Measurement. London. Charles E. MERRIL Publishing Company.

[8] Gay \& Airasian. 2000. Educational Research. Ohio. Prentice Hall, Inc.

[9] Jackendoff, Ray. 2003. Foundation of Language. New York. Oxford University Press.

[10] Johnson \& Johnson. 2002. Meaningful Assessment. Sydney. Allyn \& Bacon Company.

[11] Joyce \& Weil. 1992. Models of Teaching. London. Allyn and Bacon Publication.

[12] Ken, Springer. 2010. Educational Research. New York. John Wiley \& Sons, Inc.

[13] Mori \& Tanabe. 2015. Influence of Instructor Personality on Student Evaluation of Teaching. English Language Teaching; Vol. 8, No. 1. URL: http://dx.doi.org/10.5539/elt.v8n1p1 Retrieved by : December 17, 2014.

[14] Naga, Dali S. 1992. Teori Sekor. Jakarta. Gunadarma Press. 